\title{
IMPAKT OF THE NUMBER OF SOMATIC CELLS ON MILK QUALITY
}

\author{
Tatjana Kalevska, Zora Uzunoska \& Viktorija Stamatovska \\ Faculty of Technology and Technical Sciences, \\ University St. Kliment Ohridski of Bitola \\ Dimitar Vlahov bb, 1400 Veles, Republic of Macedonia \\ e-mail: tkalevska@gmail.com
}

\begin{abstract}
One of the indicators of the hygienic quality of milk is the number of somatic cells, which is an internationally recognized parameter for the health condition of the udder. The increased number of somatic cells over $400.000 / \mathrm{ml}$ causes changes in the secretion and the chemical composition of the milk. In this research, based on the number of somatic cells, the milk is categorized in three categories. In milk from the first category the average number of somatic cells equals $444.780 / \mathrm{ml}$, $825.560 / \mathrm{ml}$ in the second and 1,242.220/ml in the third category. In milk from the first category the average contents of milk fat, proteins, lactose, dry matter, casein and whey proteins are $4.206 \%$, $3.268 \%, 4.723 \%, 12.127 \%, 2.910 \%, 0.8610 \%$ respectively. In the second category $4.106 \%, 3.192 \%$, $4.349 \%, 11.647 \%, 2.665 \%, 0.9680 \%$, and $3.989 \%, 3.139 \%, 3.964 \%, 11.092 \%, 2.386 \%, 1.1820 \%$ in milk from the third category. The $\mathrm{pH}$ value of milk in the first, second and third category is 6.627, 6.799 and 6.897 respectively. Between the three categories of milk, significant differences, at the level of $(p<0.01)$, are determined in the number of somatic cells and average contents of milk components. $A$ positive correlation in all three milk categories exists between somatic cells and the whey proteins, and a negative correlating dependency exists between the other chemical parameters and somatic cells.
\end{abstract}

Keywords: milk, quality, chemical composition, somatic cells.

\section{INTRODUCTION}

The quality of raw milk intended for processing is determined by the physico-chemical and hygienic properties. Somatic cells are a basic indicator for the hygienic quality of milk and for the health condition of the udder, which as biological structural elements of milk pass through during the normal secretory process. An increase in the number of somatic cells occurs with intramammary bacterial infection, which leads to a change of milk quality, i.e. in the secretion of milk, accompanied with qualitative and quantitative changes in the milk components, which mainly concern the reduction of the milk fat content, lactose and casein, and the increase of whey proteins [6,7]. Changes in composition and physico-chemical properties of milk are correlated with the number of somatic cells [5]. According to [10], the variation in the compositions and properties of raw milk affects certain technological operations in milk processing that reflect the composition, properties, quality and yield of the dairy products.

\section{MATERIAL AND METHODS OF WORK}

For this research, cow's milk from farms in the Kichevo region was used. The determination of the number of somatic cells and analysis of the physico-chemical composition was performed on samples from the aggregate milk. 


\section{ARTTLY $Y$}

Ipplied Resseirlohes in Technics, Technologies and Bductation

Journal of the Faculty of Technics and Technologies, Trakia University https://sites.google.com/a/trakia-uni.bg/artte/

The analysis of the chemical composition of the milk which determines the content of fat, protein, lactose and dry matter, was done with Milkoscan infrared analyzer according to the IDF 141C:2000 standard, while determining the proportion of casein and whey protein was performed according to the Kjeldahl method according to the AOAS standard, 1995. The $\mathrm{pH}$ value of the milk was measured with $\mathrm{pH}$ meter - Mettler Toledo. The number of somatic cells was determined with a fluoro-optic electronic counter - Fossomatic 5000.

Milk - enumeration of somatic cells according to standard ISO 13366/2:2006. The principle of operation of Fossomatic 5000 consists of coloring and electronic counting of the somatic cells. According to the number of somatic cells the milk was categorized in three categories: first category milk with up to $600.000 / \mathrm{ml}$ somatic cells, second category milk from 600.000 $1.000 .000 / \mathrm{ml}$ somatic cells and third category milk with above $1.000 .000 / \mathrm{ml}$ somatic cells.

\section{RESULTS AND DISCUSSION}

The average number of somatic cells in the milk is shown in Table 1.

Table 1. Average number of somatic cells in the milk from first, second and third category

\begin{tabular}{|l|c|c|c|c|c|}
\hline Indicators & $\bar{x}$ & Sd & $\min$ & $\operatorname{Max}$ & Cv (\%) \\
\hline first category & 444.780 & 84.735 & 339.000 & 586.000 & 19.051 \\
\hline second category & 825.560 & 89.208 & 690.000 & 972.000 & 10.806 \\
\hline third category & 1.242 .220 & 47.232 & 1.172 .000 & 1.306 .000 & 3.802 \\
\hline
\end{tabular}

From the results presented in Table 1 it is noted that average the number of somatic cells in the milk from the first category is 444.780 (min.339.000 up to max.586.000), 825.560 (min.690.000 up to max.972.000) in the milk from the second category and in the milk from the third category the number of somatic cells is 1.242 .220 (min.1.172.000 up to $\max$ 1.306.000).

The results for the active acidity $(\mathrm{pH})$ of milk from the three categories is presented in Table 2.

Table 2. Average $\mathrm{pH}$ values of the milk from the three categories

\begin{tabular}{|l|l|l|l|l|r|}
\hline Indicators & $\bar{x}$ & Sd & $\min$ & $\max$ & Cv (\%) \\
\hline First category & 6.627 & 0.024 & 6.610 & 6.680 & 0.356 \\
\hline Second category & 6.799 & 0.052 & 6.720 & 6.870 & 0.761 \\
\hline Third category & 6.897 & 0.027 & 6.840 & 6.940 & 0.387 \\
\hline
\end{tabular}

From the presented results in the table, certain variations in the $\mathrm{pH}$ values between the three milk categories can be observed. In the milk from the first category the $\mathrm{pH}$ value is 6.627 (min.6.610 up to max.6.680) and 6.799 (min.6.720 up to max.6.870) in the milk from the second category. The highest $\mathrm{pH}$ value of 6,897 (min.6,840 up to max. 6,940) was found in the milk from the third category.

According to [2] with an increase in the number of somatic cells in the milk, the $\mathrm{pH}$ value is increased above the normal and is approximately $(\mathrm{pH}=7)$. The rise in $\mathrm{pH}$ value is due to an increase in the flow of blood constituents in the alveoli which then cross into the milk.

The average chemical composition of milk from the three categories is shown in Table 3.

IRTIIE Vol. 6, No. 1, 2018 ISSN 1314-8788 (print), ISSN 1314-8796 (online), doi: 10.15547/artte.2018.01.007 

https://sites.google.com/a/trakia-uni.bg/artte/

Table 3. Chemical composition of milk from first, second and third categories

\begin{tabular}{|c|c|c|c|c|c|c|c|}
\hline $\begin{array}{c}\text { Milk } \\
\text { category }\end{array}$ & $\begin{array}{l}\text { Indi } \\
\text { cators }\end{array}$ & Fat & Proteins & Casein & $\begin{array}{c}\text { Whey } \\
\text { proteins }\end{array}$ & Lactose & Dry matter \\
\hline \multirow{5}{*}{ First } & $x$ & 4.206 & 3.268 & 2.910 & 0.8610 & 4.723 & 12.197 \\
\hline & Sd & 0.044 & 0.046 & 0.067 & 0.0232 & 0.062 & 0.151 \\
\hline & Min & 4.14 & 3.20 & 2.789 & 0.8213 & 4.62 & 11.96 \\
\hline & Max & 4.28 & 3.30 & 2.991 & 0.8931 & 4.80 & 12.42 \\
\hline & $\begin{array}{l}\text { Cv } \\
(\%)\end{array}$ & 1.058 & 1.412 & 2.311 & 2.6946 & 1.313 & 1.240 \\
\hline \multirow{5}{*}{ Second } & $\bar{x}$ & 4.106 & 3.192 & 2.665 & 0.9680 & 4.349 & 11.647 \\
\hline & Sd & 0.031 & 0.035 & 0.069 & 0.0225 & 0.129 & 0.188 \\
\hline & Min & 4.06 & 3.15 & 2.523 & 0.9310 & 4.17 & 11.41 \\
\hline & Max & 4.16 & 3.26 & 2.774 & 0.9981 & 4.54 & 11.94 \\
\hline & $\begin{array}{l}\text { Cv } \\
(\%)\end{array}$ & 0.763 & 1.083 & 2.620 & 2.3247 & 2.971 & 1.612 \\
\hline \multirow{5}{*}{ Third } & $x$ & 3.989 & 3.139 & 2.386 & 1.1820 & 3.964 & 11.092 \\
\hline & $\mathrm{Sd}$ & 0.022 & 0.014 & 0.063 & 0.0340 & 0.094 & 0.110 \\
\hline & Min & 3.96 & 3.12 & 2.291 & 1.1053 & 3.81 & 10.91 \\
\hline & $\operatorname{Max}$ & 4.03 & 3.16 & 2.482 & 1.2243 & 4.10 & 11.25 \\
\hline & $\begin{array}{l}\mathrm{Cv} \\
(\%)\end{array}$ & 0.559 & 0.462 & 2.652 & 2.8930 & 2.375 & 0.988 \\
\hline
\end{tabular}

The results shown in Table 3 indicate certain variations in the chemical composition of the milk from the three categories, which are correlated with the number of somatic cells. The average content of fat in the milk from the first category is $4.206 \%$ ( $\mathrm{min} .4 .14 \%$ up to max. $4.28 \%$ ), $4.106 \%$ (min. $4.06 \%$ up to max. $4.16 \%$ ) in the milk from the second category and $3.989 \%$ (min. $3.96 \%$ up to max. $4.03 \%$ ) in the milk from the third category. From the results a certain decrease in the fat content can be noted, which corresponds with the increase in the number of somatic cells in the milk.

The average content of protein in the milk from the first category is $3.268 \%$ (min. $3.20 \%$ up to $\max .3 .30 \%), 3.192 \%$ ( $\min .3 .15 \%$ to $\max .3 .26 \%$ ) in the milk from the second category and $3.139 \%$ (min.3,12\% to max. 3,16\%) in the milk from the third category. No larger variations were observed in the amount of protein in the milk from the three categories, and it can be concluded that the increase in the number of somatic cells in the milk does not significantly affect the total protein content [4].

Unlike the total protein content of the milk, the results in Table 3 indicate a significant decrease in the content of the main milk protein casein. In the milk from the first category the average content of casein is $2.910 \%$ (min. $2.789 \%$ up to max. $2.991 \%$ ), $2.665 \%$ (min.2.523\% up to max. 2.774\%) in the milk from the second category, and the decrease in the casein content is most pronounced in the milk from the third category $2.386 \%$ (min.2.291\% to max. 2.482\%), where the number of somatic cells is greatest. The IRTIIE Vol. 6, No. 1, 2018 ISSN 1314-8788 (print), ISSN 1314-8796 (online), doi: 10.15547/artte.2018.01.007 


\section{ARTTIE $Y$}

Ipplied Resseirlohes in Technics, Technologies and Bductation

Journal of the Faculty of Technics and Technologies, Trakia University https://sites.google.com/a/trakia-uni.bg/artte/

differences in the percentage of casein among the three milk categories are significant at the level of $(p<0.01)$. The decrease is due to the reduction of synthesis and secretion of casein, and predominantly due to its post - secretory degradation under the influence of the proteolytic enzyme - plasmin.

The results show a significant increase in the content of whey protein in the three milk categories, corresponding to the increase in the number of somatic cells $[1,8]$. In the milk from the first category, the average content of whey protein is $0.8610 \%$ (min. $0.8213 \%$ up to max. $0.8931 \%$ ) and $0.9680 \%$ (min. $0.9310 \%$ up to max. $0.9981 \%$ ) in the milk from the second category. The highest content of whey protein, $1.1820 \%$ (min.1.1053\% up to max.1.2243\%) was determined in the milk from the third category. Highly significant differences in the content of whey protein were determined among the three categories of milk $(p<0.01)$. As the content of whey protein increases as a result of altered vascular permeability, the milk's thermostability decreases [3]. Greater variation was found in the content of lactose among the three categories of milk. The amount of lactose decreases respectively with the increase of the number of somatic cells in the milk. In the milk from the first category, the average lactose content is $4.723 \%$ ( $\min .4 .62 \%$ up to $\max .4 .80 \%$ ), $4.349 \%$ (min. $4.17 \%$ to max.4.54\%) in the second category and in the milk from the third category, the average lactose content is $3.964 \%$ ( $\min .3 .81 \%$ to $\max 4.10 \%$ ). In the three categories of milk, highly significant differences in the lactose content were found $(p<0.01)$. According to [9], the physiological minimum of lactose is $4.55 \%$ and each reduction indicates an increase in the number of somatic cells in the milk [10].

The results show a decrease in the dry matter content of the three categories of milk, which is understandable and in relation to the reduction of the content of the milk components. In the milk from the first category, the average content of dry matter is $12.197 \%$ ( $\min .11 .96 \%$ up to max. $12.42 \%$ ), $11.647 \%$ (min. $11.41 \%$ up to max.11.94\%) in the milk from the second category and the smallest content of dry matter was determined in the milk from the third category and amounts to $11.092 \%$ (min.10.91\% up to max. $11.25 \%$ ).

During the research, the correlations between the number of somatic cells and certain parameters for the chemical composition of the milk from the three categories were examined, and the results obtained are shown in Table 4.

Table 4. Correlations between the number of somatic cells and certain parameters for the chemical composition of milk

\begin{tabular}{|l|r|r|r|}
\hline \multicolumn{1}{|c|}{ Parameters } & r & r & \multicolumn{1}{c|}{ r } \\
\hline Somatic cells and fat (\%) & -0.966 & -0.972 & -0.785 \\
\hline Somatic cells and proteins (\%) & -0.989 & -0.804 & -0.336 \\
\hline Somatic cells and lactose (\%) & $-0,997$ & $-0,871$ & -0.655 \\
\hline Somatic cells and dry matter (\%) & -0.995 & -0.910 & -0.654 \\
\hline Somatic cells and casein (\%) & -0.901 & -0.961 & -0.952 \\
\hline Somatic cells and whey proteins (\%) & 0,943 & 0,872 & 0.909 \\
\hline Somatic cells and yield (\%) & -0.969 & -0.922 & -0.966 \\
\hline
\end{tabular}

From the examined correlation relationships between the somatic cells and the chemical parameters in milk from the three categories, negative values were found between somatic cells and fat, proteins, lactose, dry matter and casein, while a positive correlative dependence was found between somatic cells and whey proteins $(r=0.943), \quad(r=0.872)$, $(r=0.909)$. 


\section{ARTTIE $Y$}

Ipplied Resseirlohes in Technics, Technologies and Bductation

Journal of the Faculty of Technics and Technologies, Trakia University https://sites.google.com/a/trakia-uni.bg/artte/

\section{CONCLUSION}

Based on the results obtained from this research, it can be concluded that there are significant differences in the physico-chemical composition of the milk from the three categories corresponding to the increase in the number of somatic cells.

The increase in the number of somatic cells in milk affects the changes in certain milk components, especially in reducing the content of lactose and casein, which leads to an increase in the content of whey protein.

The changes in the chemical composition of the milk correspond to the increased number of somatic cells and are more pronounced in the milk from the second category, but most of all in the milk from the third category, where the number of somatic cells is $1.242 .220 / \mathrm{ml}$. In this milk category the lactose content is quite low, amounting to $3.964 \%$, the average content of casein amounts to $2.368 \%$, while the whey proteins have the greatest average value and are $1.1820 \%$.

Changes in the chemical composition and properties of milk caused by an increased number of somatic cells, lead to a decrease in the quality and yield of dairy products from its processing, and thus to economic losses in the dairy industry.

\section{REFERENCES}

[1] Boot J., (1973): Mastitis in dairy cows. Vet record. 93.

[2] Harmon, R.J.: (1994): Physiology of mastitis and factors affecting somatic cell count. Journal of dairy science 77.

[3] Jones, G.M, and J.R. Bailey: (1998): Mastitis Control in Heifers and First Lactation. Virginia Cooperative Extension, Publication Number: 404/281.

[4] Katić V., Tayeb El Huda, Babić, Lj., Popović, J.: (1994): Uticaj mastitisa na kvalitet mleka. Veterinarski glasnik, 271-276.

[5] Katić V., Stojanović L.: (1998): Uticaj mastitisa na higijensku ispravnost mleka. Jugoslovenski mlekarski simpozijum „Kvalitet mleka i fermentisanih proizvoda”, Zlatibor.

[6] Miljkovic,V, Stojanovic, (1984): Efikasnost mera suzbijanja mastitisa u krava i higijeni mleka i proizvodi od mleka. Opatija.

[7] Niketić G. Anka j. Kasalica, Dragica Ž Miočinovic, Miladin.M.Gavric (2003): Uticaj mastitisa na podobnost mleka za preradu u sir. Prehrambena industrija 1-2.

[8] Rise, D. N. I Bodman, G. R. (1997): The Somatic Cell Count and Milk Quality. http//ianrpubs.unl.edu/dairy/g1151.htm.

[9] Rupić, V., Havranek, J.: (2003): Mlijeko od farme do mljekare. Hrvatska mljekarska udruga. Zagreb.

[10] Srbinovska S.: (2007): Higiena i kvalitet mleka u Republici Makedoniji u saglasnosti legislativom Savremena Poljoprivreda vol.56,5 (2007) str.61-68, Novi Sad. 